\title{
Consumer visual appraisal and shelf life of leg chops from suckling kids raised with natural milk or milk replacer
}

\author{
Guillermo Ripoll ${ }^{1 \dagger}$, María J. Alcalde ${ }^{2}$, Anastasio Argüello ${ }^{3}$, María G. Córdoba ${ }^{4}$ \\ and Begoña Panea ${ }^{1}$ \\ ${ }^{1}$ Centro de Investigación y Tecnología Agroalimentaria de Aragón CITA. Instituto \\ Agroalimentario de Aragón - IA2 CITA-Universidad de Zaragoza, 50.059 Zaragoza, \\ Spain. \\ ${ }^{2}$ Departamento de Ciencias Agroforestales, Universidad de Sevilla. 41.013 Crta. Utrera, \\ Sevilla, Spain. \\ ${ }^{3}$ Universidad de Las Palmas de Gran Canaria. 35.416 Las Palmas, Spain. \\ ${ }^{4}$ Nutrición y Bromatología. Instituto Universitario de Investigación de Recursos \\ Agrarios (INURA). Escuela de Ingeniería Agrarias, Universidad de Extremadura. Avda. \\ Adolfo Suarez s/n, 06007 Badajoz, España.
}

$\dagger$ Corresponding author: Guillermo Ripoll; email: gripoll@aragon.es. Centro de Investigación y Tecnología Agroalimentaria de Aragón (CITA). Avda. Montañana, 930, 50059, Zaragoza, Spain. Tel.: +34 976716 452, Fax:+34 976716335

\begin{abstract}
BACKGROUND: The use of milk replacers to feed suckling kids could affect the shelf life and appearance of the meat. Leg chops were evaluated by consumers and the instrumental color was measured. A machine learning algorithm was used to relate them. The aim of this experiment was to study the shelf life of the meat of kids reared with dam's milk or milk replacers and to ascertain which illuminant and instrumental color variables are used by consumers as criteria to evaluate that visual appraisal.
\end{abstract}

This article has been accepted for publication and undergone full peer review but has not been through the copyediting, typesetting, pagination and proofreading process, which may lead to differences between this version and the Version of Record. Please cite this article as doi: 10.1002/jsfa.8758 
RESULTS: Meat from kids reared with milk replacers was more valuable and had a longer shelf life than those reared with natural milk. Consumers used the color of the whole surface of the leg chop to assess the appearance of meat. Lightness and hue angle were the prime cues used to evaluate the appearance of meat.

CONCLUSIONS: Illuminant D65 was more useful for relating the visual appraisal with the instrumental color using a machine learning algorithm. The machine learning algorithms showed that the underlying rules used by consumers to evaluate the appearance of suckling kid meat are not at all linear and can be computationally schematized into a simple algorithm.

Keywords: rearing system; survival analysis; color; machine learning; muscles; appearance

\section{INTRODUCTION}

Goats are regarded worldwide as an important species due to their contributions to the development of rural areas and communities ${ }^{1}$. Spain has one of the largest goat populations in Europe, producing the $20 \%$ of the goat milk and the $10.9 \%$ of the kid meat in the European Union ${ }^{2}$. In addition to this, the sale of suckling kids makes up 20 $\%$ of the total income per goat on the dairy farm ${ }^{3}$, and $80 \%$ of this kid meat originates from the suckling kid category (cabrito) ${ }^{4}$. These suckling kids have a live weight of 10 $11 \mathrm{~kg}$ and a carcass weight of $5-7 \mathrm{~kg}$ and are perceived by consumers to be a highquality meat ${ }^{5}$. In fact, $88 \%$ of European Union goats are raised extensively and slaughtered as kids, with carcass weights of between $5 \mathrm{~kg}$ and $11 \mathrm{~kg}^{6}$. When kid goats are reared with their dams, the availability of milk for cheese production is decreased. Therefore, some goat farmers remove the kids from their dams at a very young age and rear them with milk replacers. Milk replacers specifically formulated for kids can result in good daily weight gain. However, some farmers are disinclined to use milk replacers because that this type of rearing involves greater labor costs, although total costs are equal or greater than natural suckling systems ${ }^{7,8}$.

Meat color is an extremely important factor for influencing consumer purchase decisions, as it is deemed a visual measure of freshness and quality ${ }^{9}$ and plays a major role in the purchase decision ${ }^{10,11}$. In Mediterranean countries, some people believe that light colored meat lamb and goat comes from young animals. Spanish consumers in

This article is protected by copyright. All rights reserved. 
particular thinks that meat from suckling kids and lambs had better sensory quality than older animals and they are willing to pay higher prices ${ }^{12}$. The meat color of young small ruminants is influenced by factors in the management system ${ }^{13}$ such as breed, age/weight at slaughter, $\mathrm{pH}$ and the use of milk replacers ${ }^{14}$. In addition to the influence of milk replacer use on meat color, consumers' visual appraisal of kid meat quality is affected by the conditioning associated with their socio-demographic characteristics ${ }^{15}$. Accordingly, a fresh appearance and light color in lamb were more highly valued by traditional consumers ${ }^{11}$ and can determine purchase intention. However, in other species such as beef, the influence of demographic factors on acceptability are less important ${ }^{16}$.

In 1931, the Comite International de L'Eclairage (CIE) recommended the use of illuminant $\mathrm{C}$. However, in current times, this illuminant has seemed inadequate due to a deficient spectral distribution in the ultraviolet region. The Illuminant $\mathrm{A}$ is frequently used in North America ${ }^{17}$. AMSA ${ }^{18}$ recommended the use of the illuminant A when the detection of redness differences between treatments is the priority because illuminant $\mathrm{A}$ places more emphasis on the proportion of red wavelengths; this results in higher a* values than with the use of D65 ${ }^{19}$. However, kid meat has a low heminic pigment content, resulting in a pale meat with a low redness index ${ }^{20}$. Consequently, it is unclear which illuminant should receive preferential use to correctly relate the instrumental color of the kid meat with the visual appraisal of consumers.

In this article, we argue that consumers perform their visual appraisal of meat by means of knowledge that can be computationally schematized. This approach has been applied before to beef color, demonstrating that the relationship between CIEL*a*b* color variables and the perception of beef color by humans is not linear ${ }^{21}$.

The aim of this experiment was to study the shelf life of the meat of kids reared with dam's milk or milk replacers and to determine which muscles of the leg are more important in the visual appraisal by consumers and which illuminant and instrumental color variables are used by consumers as criterion to evaluate in their visual appraisal.

\section{MATERIAL AND METHODS}

\section{Carcass sampling}

This article is protected by copyright. All rights reserved. 
Suckling male kids of the Cabra del Guadarrama breed reared with milk replacers $(\mathrm{MR})$ or natural milk from their dams $(\mathrm{NM})$ were selected from two farms. Fifteen MR kids and 16 NM kids were slaughtered following standard commercial procedures according to the European norms for the protection of animals at the time of killing ${ }^{22}$. Kids had a liveweight of $8.6 \pm 0.27 \mathrm{~kg}$ and age of $40-45 \mathrm{~d}$ old $(\mathrm{P}>0.05)$. A head-only electrical stunning $(1.00 \mathrm{~A})$ was applied to the kids, which were then were exsanguinated and dressed with a hot carcass weight of $5.8 \mathrm{~kg} \pm 0.17 \mathrm{~kg}(\mathrm{P}>0.05)$. Carcasses were hung by the Achilles tendon and transported at $4^{\circ} \mathrm{C}$ to the facilities of the CITA Research Institute at Zaragoza. Then, the carcasses were chilled for $24 \mathrm{~h}$ at $4^{\circ} \mathrm{C}$ in total darkness. The right hind leg was separated from the carcass, vacuum packed and stored at $-20^{\circ} \mathrm{C}$ until sampling.

\subsection{Color measurement of the chops}

The shelf life of meat of suckling lambs and kid's goat are around a week ${ }^{23,24}$. Because the very small size of legs of kids, only four of the leg chops were enough big to measure the color of the different muscles. Hence, the 31 frozen legs were sliced into four chops assigned to $8,6,3$ and 1 days before the day of the visual appraisal by consumers (day 0). On the assigned day, the chops were thawed and placed in polystyrene trays covered with oxygen permeable film and then stored for $24 \mathrm{~h}$ at $4^{\circ} \mathrm{C}$ in total darkness until the day of the visual appraisal. The semimembranosus, semitendinosus and biceps femoris muscles of the leg were located ${ }^{25,26}$, and their instrumental color measured. These muscles were selected because they are the muscles that represent most of the area of the chop. Color measurements were repeated two or three times depending on the reading area of the muscle. The spectrophotometer was rotated $90^{\circ}$ on the horizontal plane, and the mean of these 2-3 readings was used for analysis ${ }^{27}$.

Muscle colors were measured using a Minolta CM-2006d spectrophotometer (Konica Minolta Holdings, Inc, Osaka, Japan) in CIEL*a*b* space ${ }^{28}$ with the specular component included, $0 \% \mathrm{UV}$, an observer angle of $10^{\circ}$ and zero and white calibration. The integrating sphere had a $52 \mathrm{~mm}$ diameter, and the measurement area (diameter of 8 mm) was covered with a CM-A149 dust cover (Konica Minolta Holdings, Inc, Osaka, Japan). The illuminants used were D65, C and A. The lightness ( $\left.\mathrm{L}^{*}\right)$, redness $\left(\mathrm{a}^{*}\right)$ and yellowness $\left(b^{*}\right)$ indexes were recorded using the software SpectraMagic NX (Minolta

This article is protected by copyright. All rights reserved. 
Co. Ltd., Osaka, Japan), and the hue angle $\left(h_{a b}\right)$ and chroma $\left(\boldsymbol{C}_{\boldsymbol{a b}}^{*}\right)$ indexes were calculated as $h_{a b}=\tan ^{-1}\left(\frac{b *}{a *}\right) \cdot 57.29$ and expressed in degrees as $C_{a b}^{*}=$ $\sqrt{(a *)^{2}+(b *)^{2}}$.

When the color of every chop was measured, four MR and four NM chops from each time of storage ( $1 \mathrm{~d}, 3 \mathrm{~d}, 6 \mathrm{~d}$ and $8 \mathrm{~d}$ ), with values of $\mathrm{L}^{*}, h_{a b}$ and $\boldsymbol{C}_{\boldsymbol{a b}}^{*}$ for the three muscles representative of the 31 chops (Table 1), were selected for the visual appraisal of the consumers. $\mathrm{L}^{*}, h_{a b}$ and $\boldsymbol{C}_{\boldsymbol{a} \boldsymbol{b}}^{*}$ were chosen because these parameters are similar to the color perception of human beings (Ripoll, Panea, \& Albertí, 2012; Wyszecki \& Styles, 1982).

\section{Evaluation of the appearance of the chops}

On the day of the visual appraisal, the eight chops were identified with 3 digit random numbers and randomly placed in a refrigerated island display case, Carrier Multinor 1540/80, with a display area of $1 \mathrm{~m}^{2}(1.3 \mathrm{~m} \mathrm{x} 0.8 \mathrm{~m})$ (Carrier Refrigeración Ibérica SA, Spain) at $0-2{ }^{\circ} \mathrm{C}$. Samples were available from 8:00 am to $16: 00 \mathrm{pm}$, and to avoid the possible effects of the order of presentation, and first-order and carry-over effects, the samples were moved randomly three times through the test day. The lightning was provided by LED bulbs with a luminous flux of 816 lumen, a color temperature of $4000 \mathrm{~K}$, a color rendering index $>80$ and a standard deviation color matching equal to 3 MacAdam ellipses ${ }^{29}$. The illuminance on the surface of the chops was approximately $1300 \mathrm{~lx}$, ensuring the minimum level of illuminance in areas with high visual requirements ${ }^{30}$.

The participation of naïve consumers in the experiment was voluntary and anonymous. Consumers were recruited among students and workers, without relation with the current research, of Aula Dei Campus. Personal data as identification or electronic mail were not required, and there was no financial compensation. Participants were clearly informed of aim of the study and gave implicit consent for research use of the supplied information according to European regulations ${ }^{31}$. Each consumer was provided with a form in which they were asked about their gender and age. Regarding the chops, the consumers were asked to evaluate from 1 (very bad) to 10 (very good) the color-based appearance of the chops. Additionally, they were asked about their purchase intention (yes/no). The leg chops displayed on the island case were evaluated by 56

This article is protected by copyright. All rights reserved. 
respondents: $67.9 \%$ female and $32.1 \%$ male. Their ages were equally distributed by sex $(\mathrm{P}>0.05): 5.7 \%$ were younger than 24 years, $26.4 \%$ were between 26 and 40 years, $39.6 \%$ were between 41 and 55 years, and $28.3 \%$ were older than 55 years. Participants took 10-20 min to complete the required tasks.

\section{Statistical analysis}

Statistical analyses were performed with SAS 9.4 (SAS Institute Inc., EE.UU.) 32. Instrumental color variables were analyzed using the GLM procedure with the rearing system, the time of storage and the muscle as fixed effects. Visual appraisal was analyzed using the GLM procedure, with the rearing system and the time of storage as fixed effects. Least square means were estimated, and differences were tested at a 0.05 level of significance. The Pearson correlations between the visual appraisal and the instrumental color of the three muscles with the two used standard illuminants were calculated with the residuals of each observation.

The association between the rearing system and time of display for the purchase intention was analyzed by a chi-square test. The meat shelf life according to the consumer's purchase intention was studied using the survival analysis of Kaplan-Meier with the LIFETEST procedure. The log rank test was used to examine the differences between the survival curves. The estimate of the shelf life was the median, that is, the day on which $50 \%$ of the consumers rejected the samples.

A machine learning algorithm Cubist $2.099^{33}$ was used to generate rule-based predictive models from the color variables of the muscles studied. This algorithm uses the input data to generate a decision tree with linear functions in all leaves. The relative error magnitude is the ratio of the average error magnitude to the error magnitude that would result from always predicting the mean value; for useful models, this should be less than 1 . The correlation coefficient measures the agreement between the cases' actual values for the target attribute and those values predicted by the model ${ }^{33}$.

\section{RESULTS}

The leg chops selected to be exposed in the display case were representative of the other leg chops because they had similar $\mathrm{L}^{*}, h_{a b}$ and $C_{a b}^{*}$ values for each muscle $(\mathrm{P}>0.005)$ (Table 1).

The instrumental colors of the leg chops are shown in Table 2. The rearing system had a significant effect on every color variable, except $C_{a b}^{*} \quad(\mathrm{P}=0.056)$. 
Accordingly, MR had greater $\mathrm{L}^{*}, \mathrm{~b}^{*}$ and $h_{a b}$ but lower $\mathrm{a}^{*}(\mathrm{P}<0.05)$. Values of $\mathrm{a}^{*}$ and $C_{a b}^{*}$ decreased with the time of display $(\mathrm{P}<0.05)$, but the other variables did not change with time $(\mathrm{P}>0.05)$. The three muscles differed in terms of $\mathrm{a}^{*}, \mathrm{~b}^{*}$ and $C_{a b}^{*}(\mathrm{P}<0.005)$. The muscles biceps femoris and semimembranosus had the same $\mathrm{a}^{*}$ and $\mathrm{b}^{*}$ values $(\mathrm{P}>0.05)$, although semimembranosus and semitendinosus muscles had similar $C_{a b}^{*}$ values $(\mathrm{P}>0.05)$.

The visual appraisal of leg chops throughout the time of display is shown in Figure 1. The effect of the rearing system and the effect of time of display were significant $(\mathrm{P}<0.001)$, but the interaction was not $(\mathrm{P}=0.746)$. MR showed greater visual appraisal than NM over all times of display, with the exception of 6 days $(\mathrm{P}>0.05)$. Leg chops from both rearing systems decreased significantly in the visual appraisal from $1 \mathrm{~d}$ to $6 \mathrm{~d}$. Visual appraisal at $8 \mathrm{~d}$ was also lower than that at $3 \mathrm{~d}(\mathrm{P}<0.05)$. The visual appraisal of MR was always greater than 6, while the visual appraisal of NM was between 5 and 6 from the 6 th day.

The purchase intention of consumers at each time of display is shown in Figure 2. The rearing system and time of display were independent effects $(\mathrm{P}=0.997)$. The purchase intention was greater for MR than NM throughout the whole time of display. Hence, more than the $50 \%$ of consumers purchased the MR leg chops at any time of display, while fewer than $50 \%$ of consumers purchased NM leg chops at 6 and $8 \mathrm{~d}$.

The median shelf life of leg chops (Table 3) estimated according the purchase intention was affected by the rearing system $(\mathrm{P}=0.005)$, but the sex and age of consumers did not have an effect $(\mathrm{P}>0.1)$. The global shelf life of leg chops was $6 \mathrm{~d} \pm$ 0.6. However, the shelf life for MR was $8 \mathrm{~d}$, while the shelf life for NM was 6 .

Table 4 shows the significant correlations among the residuals of the visual appraisal with the color variables for each muscle and illuminant used. Significant correlations were not found for the color of biceps femoris and semimembranosus with any illuminant used for any color variable. Visual appraisal of leg chops did not correlate with $\mathrm{a}^{*}$ or $C_{a b}^{*}$ of the semitendinosus when measured with any of the three illuminants. Correlations using $\mathrm{C}$ and D65 provided similar correlations, but $\mathrm{a}^{*}$ measured with illuminant A correlated more closely than when measured with $\mathrm{C}$ and D65. Conversely, $C_{a b}^{*}$ when measured with illuminant A correlated less than when measured with $\mathrm{C}$ and D65. When the three muscles were averaged, $\mathrm{L}^{*}$ was negative and highly correlated with visual appraisal, providing similar results to the three illuminants used.

This article is protected by copyright. All rights reserved. 
The quality statistics of several models proposed by the machine learning algorithm are shown in Table 5. In this table, the color variables included in each model are also provided. The global model using the averaged color variables of the three muscles was measured with the three illuminants and had a relative error of 0.81 , as well as a correlation between the real visual appraisal of consumers and the predicted values of 0.52 . The models that used the colors of all three muscles and their averaged color variables when measured with D65 and C showed better statistical correlation. The use of both illuminants also provided better results than the use of the same model with illuminant A. Due to the good results found for illuminant D65, this illuminant was used to develop separate models with each muscle. As a result, these three models showed less consistent statistical results than the model that included the three muscles averaged and measured with illuminant D65; however, the results were still more similar than those which used illuminant A. Consequently, the best model was the model which used the color measurements for the three muscles and their average color, measured with the illuminant D65. The machine learning algorithm proposed two linear regression equations depending on the averaged $L^{*}$. That is:

If $\mathrm{L}^{*}(\square)>40.77$ then

Eq.1:

Visual appraisal $=-11.2+12.418 \cdot h_{a b}(\square)-4.185 \cdot h_{a b}(\mathrm{BF})-4.13 \cdot h_{a b}(\mathrm{SM})-3.821 \cdot h_{a b}(\mathrm{ST})-1.89 \cdot \mathrm{b}^{*}(\mathrm{ST})$

$+1.73 \cdot C_{a b}^{*}(S T)+0.14 \cdot b^{*}(\mathrm{ST})+0.14 \cdot \mathrm{a} *(\mathrm{ST})$

If $\mathrm{L}^{*}(\square) \leq 40.77$ then

Eq. 2:

Visual appraisal $=-16.1+4.539 \cdot h_{a b}(\square)-1.679 \cdot h_{a b}(\mathrm{BF})-1.428 \cdot h_{a b}(\mathrm{SM})-1.321 \cdot h_{a b}(\mathrm{ST})-0.65 \cdot \mathrm{b}^{*}(\mathrm{ST})$

$+1.98 \cdot C_{a b}^{*}(S T)-0.21 \cdot \mathrm{a} *(\mathrm{ST})$,

where BF is biceps femoris, $\mathrm{ST}$ is semitendinosus, $\mathrm{SM}$ is semimembranosus and $\square$ is the averaged value of the three muscles.

Both eq. 1 and eq. 2 use the averaged $h_{a b}$ and the $h_{a b}$ of the three muscles, followed by the $\mathrm{a}^{*}, \mathrm{~b}^{*}$ and $C_{a b}^{*}$ of the semitendinosus, which is the muscle with greater values of these variables.

\section{DISCUSSION}

This article is protected by copyright. All rights reserved. 
Meat from suckling kids with very light carcass weight (approximately $5 \mathrm{~kg}$ ) is characterized by high $\mathrm{L}^{*}$ and low $\mathrm{a}^{*}$ and $\mathrm{b}^{*}$ values, resulting in a lighter, paler and duller meat ${ }^{34,35}$ compared with other meats such as beef, even for suckling kids with heavier carcasses ${ }^{36,37}$ and concentrate-fed kids ${ }^{38}$. Changes in the color of kid meat with increases in age/weight have been reported by other authors, especially the increase in redness intensity ${ }^{39-41}$ and the decrease in lightness ${ }^{41,42}$ and hue angle ${ }^{5}$.

Diet strongly affects the meat color of preruminants such as suckling lambs and kids ${ }^{37,43}$. The lightness of meat is influenced by $\mathrm{pH}$ and protein structures ${ }^{44}$ more than diet ${ }^{45}$. Hence, milk replacer does not affect the $\mathrm{L}^{*}$ of fresh kid meat, independent of the measured muscle $35,46,47$. However, frozen/thawed meat could show a different behavior due to the denaturalization of sarcoplasmic proteins. In agreement with our results, De Palo, Maggiolino, Centoducati and Tateo ${ }^{35}$ found that the longissimus thoracis of kids fed with goat milk had lower $\mathrm{b}^{*}$ and $h_{a b}$ than that of those fed with milk replacer. Additionally, they also did not find differences in $C_{a b}^{*}$. The use of milk replacers affects the color of semimembranosus by decreasing $b^{*} 47$ compared with natural goat milk. However, the composition of the goat milk is dependent on the management system of the goats ${ }^{48}$, and this influences the color of meat, especially a*.

Meat discoloration is produced during storage as deoxymyoglobin is converted to metmyoglobin. Meat discoloration is important because this meat cannot be sold easily ${ }^{49}$. Therefore, increases in $h_{a b}$ and decreases in $C_{a b}^{*}$ have been used as indicators of red meat discoloration 16,21,35,44,50-52. This is in agreement with the results of our study, which showed a decrease in a* and $C_{a b}^{*}$. However, Ozcan, Yalcintan, Tölü, Ekiz, Yilmaz and Savaş 37 studied the meat color of Gokceada suckling kids raised extensively and concluded that while $\mathrm{a}^{*}$ and $\mathrm{b}^{*}$ seemed not to change from $1 \mathrm{~d}$ to $5 \mathrm{~d}$, L* decreased slightly. Morales-De la Nuez, Falcón, Castro, Briggs, HernándezCastellano, Capote and Argüello ${ }^{34}$ did not report changes in $\mathrm{L}^{*}$ and $\mathrm{a}^{*}$ of meat from Majorera kids stored for 7 days; however, $b^{*}$ and $h_{a b}$ increased while $C_{a b}^{*}$ decreased. Changes in $h_{a b}$ and $C_{a b}^{*}$ with storage time can be a result of the oxidation of myoglobin to metmyoglobin and the loss of heminic pigments due to the freeze/thaw process.

Some studies of diverse muscle colors for lamb ${ }^{53}$ and beef ${ }^{26}$ reported greater differences in $\mathrm{L}^{*}$ than in $\mathrm{a}^{*}$ and $\mathrm{b}^{*}$ between the studied muscles. Regarding $\mathrm{a}^{*}$ and $\mathrm{b}^{*}$, Torrescano, Sánchez-Escalante, Giménez, Roncalés and Beltrán ${ }^{54}$ found results similar 
to those in our study with frozen beef. However, these authors also found differences between the three muscles in $\mathrm{L}^{*}$. M. biceps femoris could have lower $C_{a b}^{*}$ because it has more type IIb (white) fibers, while semitendinosus and semimembranosus have fiber types IIa and IIb (red) in almost the same proportions ${ }^{55}$.

Consumers showed a clear preference for MR meat, demonstrating that kid meat with greater $\mathrm{L}^{*}$ and $h_{a b}$ is preferred ${ }^{12}$. In addition, the discoloration of kid meat and the rejection of consumer are shown to relate to $C_{a b}^{*}$ rather than $h_{a b}$, likely due to the paleness of this kind of meat. Other authors also reported the importance of the relation between the visual appraisal of meat and ratios between $a^{*}$ and $b^{*}$ instead of individual trichromatic coordinates ${ }^{21,50,56}$. There is consistency between the existing correlations and the rules proposed by the machine learning algorithm. A strong relationship between visual color assessment and $\mathrm{L}^{*}$ has been reported previously ${ }^{57-59}$. Consumers used $\mathrm{L}^{*}$ as a principal cue to evaluate the suckling kid meat, but as a threshold or boundary rather than as the source for their complete evaluation. In addition to $\mathrm{L}^{*}$, consumers assessed the appearance of whole chop rather than individual muscles and focused on $h_{a b} . h_{a b}$ and $C_{a b}^{*}$ have been reported, together with $\mathrm{L}^{*}$, as variables easily interpretable by human beings. Conversely, $b^{*}$ is not intuitively related with the color of meat ${ }^{21,44,60}$, and its use by evaluators is complex ${ }^{61}$. Khliji, van de Ven, Lamb, Lanza and Hopkins ${ }^{62}$ used only $\mathrm{L}^{*}$ and $\mathrm{a}^{*}$ to score fresh lamb meat, but when browning was studied, the $630 / 580 \mathrm{~nm}$ ratio was included in the ranking models. Holman, van de Ven, Mao, Coombs and Hopkins ${ }^{16}$ found that $a^{*}$ provided the best prediction of consumer acceptance of beef color, but the use of $h_{a b}$ and $C_{a b}^{*}$ improved precision. It seems clear that $\mathrm{a}^{*}$ is the best cue to assess fresh meat. However, when browning or discoloration appears, the best parameters to assess meat are those that consider $a^{*}$ and $b^{*}$ together, e.g., $\mathrm{b}^{*} / \mathrm{a}^{*}$ or $\mathrm{a}^{*} / \mathrm{b}^{*}$ ratios, $h_{a b}, C_{a b}^{*}$, or reflectance ratios such as $630 / 580 \mathrm{~nm}$. Regarding the illuminants used, illuminant A focuses on red wavelengths and is recommended to relate the visual assessment to instrumental color ${ }^{18}$. However, D65 was more useful to find a relationship between the visual appraisals of the light and pale meat of goat kids. Results for illuminant $\mathrm{C}$ were closer to D65 because the illuminants differed in the ultraviolet region, which is not visible.

\section{CONCLUSIONS}

This article is protected by copyright. All rights reserved. 
Meat from kids reared with milk replacers was more valuable and had a longer shelf life than meat from kids reared with natural milk.

Consumers used the color of the whole surface of the leg chop, then the color of semitendinosus, to assess the appearance of meat. Lightness and hue angle were the primary cues used to evaluate the suckling kid meat. Both of these parameters were more important cues than the redness index when fresh and discolored meats were shown together. Illuminant D65 was more useful in relating the visual appraisal to the instrumental color using a machine learning algorithm.

The machine learning algorithms showed that the underlying rules used by consumers to evaluate the appearance of suckling kid meat are not at all linear and can be computationally schematized into a simple algorithm.

\section{ACKNOWLEDGMENTS}

This article is protected by copyright. All rights reserved. 
Appreciation is expressed to breeders and the staff of CITA de Aragón for their help in data collection. This study was supported by the Ministry of Economy and Competitiveness of Spain and the European Union Regional Development Funds (RTA2012-0023-C03) and the research group funds of the Aragón Government (A04).

\section{REFERENCES}

1. Dubeuf J-P, Morand-Fehr P and Rubino R, Situation, changes and future of goat industry around the world. Small Rumin Res 51:165-173 (2004).

2. MERCASA, Alimentación en España 2015. Producción, industria, distribución y consumo. Madrid, España (2016).

3. Castel JM, Mena Y, Ruiz FA and Gutiérrez R, Situación y evolución de los sistemas de producción caprina en España. Tierras Caprino 1:24-37 (2012).

4. MAPAMA, Encuesta de sacrificio de ganado del Ministerio de Agricultura y Pesca, Alimentación y Medio Ambiente Ed. Ministerio de Agricultura y Pesca, Alimentación $\quad \mathrm{y} \quad$ Medio Ambiente www.mapama.gob.es/es/estadistica/temas/estadisticas-agrarias/ganaderia/encuestassacrificio-ganado/ (2016).

5. Marichal A, Castro N, Capote J, Zamorano N and Arguello A, Effects of live weight at slaughter $(6,10$ and $25 \mathrm{~kg})$ on kid carcass and meat quality. Livest Prod Sci 83:247-256 (2003).

6. Shrestha JNB and Fahmy MH, Breeding goats for meat production 2. Crossbreeding and formation of composite population. Small Rumin Res 67:93-112 (2007).

7. Delgado-Pertínez M, Guzmán-Guerrero JL, Caravaca FP, Castel JM, Ruiz FA, González-Redondo P and Alcalde MJ, Effect of artificial vs. natural rearing on milk yield, kid growth and cost in Payoya autochthonous dairy goats. Small Rumin Res 84:108-115 (2009).

8. Delgado-Pertíñez M, Guzmán-Guerrero JL, Mena Y, Castel JM, GonzálezRedondo P and Caravaca FP, Influence of kid rearing systems on milk yield, kid growth and cost of Florida dairy goats. Small Rumin Res 81:105-111 (2009).

9. Faustman $\mathrm{C}$ and Cassens $\mathrm{R}$, The biochemical basis for discoloration in fresh meat: a review. Journal of Muscle Foods 1:217-243 (1990).

10. Mancini RA and Hunt MC, Current research in meat color. Meat Sci 71:100-121 (2005).

11. Bernués A, Ripoll $\mathrm{G}$ and Panea $\mathrm{B}$, Consumer segmentation based on convenience orientation and attitudes towards quality attributes of lamb meat. Food Qual Prefer 26:211-220 (2012).

12. Sañudo C, Sanchez A and Alfonso M, Small ruminant production systems and factors affecting lamb meat quality. Meat Sci 49:S29-S64 (1998).

13. Alcalde MJ and Negueruela AI, The influence of final conditions on meat colour in light lamb carcasses. Meat Sci 57:117-123 (2001).

14. Argüello A, Castro N, Capote J and Solomon M, Effects of diet and live weight at slaughter on kid meat quality. Meat Sci 70:173-179 (2005).

15. Panea P, Alcalde MJ, Ripoll G, Horcada A and Sañudo C, Multiple correspondence analysis as tool to study the consumer's appraisal about suckling kid meat., in Fourth European conference on sensory and consumer research Eurosense 2010, Ed. Elsevier, Vitoria,España (2010).

This article is protected by copyright. All rights reserved. 
16. Holman BW, van de Ven RJ, Mao Y, Coombs CE and Hopkins DL, Using instrumental (CIE and reflectance) measures to predict consumers' acceptance of beef colour. Meat Sci 127:57-62 (2017).

17. Tapp III WN, Yancey JWS and Apple JK, How is the instrumental color of meat measured? Meat Sci 89:1-5 (2011).

18. AMSA, Guidelines for meat color evaluation, Ed. American Meat Science Association, Champaign, Illinois, USA, p 124 (2012).

19. Yancey JWS and Kropf DH, Instrumental reflectance values of fresh pork are dependant on aperture size. Meat Sci 79:734-739 (2008).

20. Ripoll G, Alcalde MJ, Horcada A and Panea B, Suckling kid breed and slaughter weight discrimination using muscle colour and visible reflectance. Meat Sci 87:151-156 (2011).

21. Ripoll G, Panea B and Albertí P, Visual appraisal of beef: Relationship with CIELab colour space. ITEA-Información Técnica Económica Agraria 108:222-232 (2012).

22. E.U., Council Regulation (EC) No 1099/2009 of 24 September 2009 on the protection of animals at the time of killing, in Official Journal of the European Union, Ed, pp L303/301-L303/330 (2009).

23. Alcalde MJ, Suárez MD, Rodero E, Álvarez R, Sáez MI and Martínez TF, Effects of farm management practices and transport duration on stress response and meat quality traits of suckling goat kids. animal 11:1626-1635 (2017).

24. Lobón S, Sanz A, Blanco M, Ripoll G and Joy M, The type of forage and condensed tannins in dams' diet: Influence on meat shelf life of their suckling lambs. Small Rumin Res 154:115-122 (2017).

25. Popesko P, Atlas of topographical anatomy of the domestic animals. Vydavatelstvo Priroda (1977).

26. Jones SJ, Guru A, Singh V, Carpenter B, Calkins CR and Johnson D, Bovine myology and muscle profiling. http://bovine.unl.edu2017].

27. Warner RD, Kearney G, Hopkins DL and Jacob RH, Retail colour stability of lamb meat is influenced by breed type, muscle, packaging and iron concentration. Meat Sci 129:28-37 (2017).

28. CIE, Colorimetry. Centre International de L'eclairage, Vienna (1986).

29. MacAdam DL, Visual sensitivities to color differences in daylight. J Opt Soc Am 32:247-274 (1942).

30. B.O.E., Real Decreto 486/1997, de 14 de abril, por el que se establecen las disposiciones mínimas de seguridad y salud en los lugares de trabajo, in 97, Ed, España, pp 12918-12926 (1997).

31. U.E., Directiva 95/46/CE del Parlamento Europeo y del Consejo de 24 de octubre de 1995 relativa a la protección de las personas físicas en lo que respecta al tratamiento de datos personales y a la libre circulación de esos datos, in Diario Oficial de las Comunidades Europeas I281, Ed, pp 31-50 (2010).

32. S.A.S., SAS/STAT 9.3 User's Guide. SAS Institute (2014).

33. Rulequest, www.rulequest.com/cubist-info.html. www.rulequest.com/cubistinfo.html [29/12/2016 2016].

34. Morales-De la Nuez AJ, Falcón A, Castro N, Briggs H, Hernández-Castellano LE, Capote $\mathrm{J}$ and Argüello A, The effects of modified atmosphere packaging on goat kid meat quality. J Appl Anim Res 39:353-358 (2011).

35. De Palo P, Maggiolino A, Centoducati N and Tateo A, Effects of different milk replacers on carcass traits, meat quality, meat color and fatty acids profile of dairy goat kids. Small Rumin Res 131:6-11 (2015).

This article is protected by copyright. All rights reserved. 
36. Yakan A, Ates CT, Alasahan S, Odabasioglu F, Unal N, Ozturk OH, Gungor OF and Ozbeyaz C, Damascus kids' slaughter, carcass and meat quality traits in different production systems using antioxidant supplementation. Small Rumin Res 136:43-53 (2016).

37. Ozcan M, Yalcintan H, Tölü C, Ekiz B, Yilmaz A and Savaş T, Carcass and meat quality of Gokceada Goat kids reared under extensive and semi-intensive production systems. Meat Sci 96:496-502 (2014).

38. Emami A, Nasri MH, Ganjkhanlou M, Zali A and Rashidi L, Effects of dietary pomegranate seed pulp on oxidative stability of kid meat. Meat Sci 104:14-19 (2015).

39. Borgogno $\mathrm{M}$, Corazzin $\mathrm{M}$, Saccà E, Bovolenta $\mathrm{S}$ and Piasentier E, Influence of familiarity with goat meat on liking and preference for capretto and chevon. Meat Sci 106:69-77 (2015).

40. Berge P, Sanudo C, Sanchez A, Alfonso M, Stamataris C, Thorkelsson G, Piasentier E and Fisher A, Comparison of muscle composition and meat quality traits in diverse commercial lamb types. Journal of Muscle Foods 14:281-300 (2003).

41. Ripoll G, Alcalde MJ, Horcada A, Campo MM, Sanudo C, Teixeira A and Panea $\mathrm{B}$, Effect of slaughter weight and breed on instrumental and sensory meat quality of suckling kids. Meat Sci 92:62-70 (2012).

42. Bonvillani A, Peña F, de Gea G, Gómez G, Petryna A and Perea J, Carcass characteristics of Criollo Cordobés kid goats under an extensive management system: Effects of gender and liveweight at slaughter. Meat Sci 86:651-659 (2010).

43. Joy M, Sanz A, Ripoll G, Panea B, Ripoll-Bosch R, Blasco I and AlvarezRodriguez J, Does forage type (grazing vs. hay) fed to ewes before and after lambing affect suckling lambs performance, meat quality and consumer purchase intention? Small Rumin Res 104:1-9 (2012).

44. MacDougall DB, Changes in the colour and opacity of meat. Food Chem 9:7488 (1982).

45. Renerre M, La couleur de la viande et sa mesure. Bull Techn CRZV:47-54 (1982).

46. Bañón S, Vila R, Price A, Ferrandini E and Garrido MD, Effects of goat milk or milk replacer diet on meat quality and fat composition of suckling goat kids. Meat Sci 72:216-221 (2006).

47. Zurita-Herrera P, Delgado JV, Argüello A, Camacho ME and Germano R, Effects of three management systems on meat quality of dairy breed goat kids. J Appl Anim Res 41:173-182 (2013).

48. Raynal-Ljutovac K, Lagriffoul G, Paccard P, Guillet I and Chilliard Y, Composition of goat and sheep milk products: An update. Small Rumin Res 79:57-72 (2008).

49. Liu Q, Lanari MC and Schaefer DM, A review of dietary vitamin E supplementation for improvement of beef quality. Journal of Animal Science 73:31313140 (1995).

50. Lee S, Decker E, Faustman $\mathrm{C}$ and Mancini R, The effects of antioxidant combinations on color and lipid oxidation in $\mathrm{n}-3$ oil fortified ground beef patties. Meat Sci 70:683-689 (2005).

51. Albertí P, Ripoll G, Casasús I, Blanco M, Chapullé JLG and Santamaría S, Effect of the addition of antioxidants to finishing diets of young bulls on meat quality. ITEA-Información Técnica Económica Agraria 101:91-100 (2005).

52. Ripoll G, Joy M and Muñoz F, Use of dietary vitamin E and selenium (Se) to increase the shelf life of modified atmosphere packaged light lamb meat. Meat Sci 87:88-93 (2011).

This article is protected by copyright. All rights reserved. 
53. Tschirhart-Hoelscher TE, Baird BE, King DA, McKenna DR and Savell JW, Physical, chemical, and histological characteristics of 18 lamb muscles. Meat Sci 73:4854 (2006).

54. Torrescano G, Sánchez-Escalante A, Giménez B, Roncalés P and Beltrán JA, Shear values of raw samples of 14 bovine muscles and their relation to muscle collagen characteristics. Meat Sci 64:85-91 (2003).

55. Totland GK and Kryvi H, Distribution patterns of muscle fibre types in major muscles of the bull (Bos taurus). Anatomy and embryology 184:441-450 (1991).

56. Morrissey ER, Jacob RH and Pluske JM, Perception of red brown colour by consumers, in 54th International Congress of Meat Science and Technology, Ed by Webb E, Hoffman L, Strydom P and Frylinck L. Elsevier, Cape Town, South Africa (2008).

57. Hulsegge B, Engel B, Buist W, Merkus GSM and Klont RE, Instrumental colour classification of veal carcasses. Meat Sci 57:191-195 (2001).

58. Eikelenboom G, Hoving-Bolink AH and Hulsegge B, Evaluation of invasive instruments for assessment of veal colour at time of classification. Meat Sci 31:343-349 (1992).

59. Denoyelle C and Berny F, Objective measurement of veal color for classification purposes. Meat Sci 53:203-209 (1999).

60. Mancini RA, Hunt MC, Hachmeister KA, Seyfert MA, Kropf DH, Johnson DE, Cusick $\mathrm{S}$ and Morrow $\mathrm{C}$, The utility of lactate and rosemary in beef enhancement solutions: Effects on longissimus color changes during display. Journal of Muscle Foods 16:27-36 (2005).

61. O'Sullivan MG, Byrne DV, Martens H, Gidskehaug LH, Andersen HJ and Martens M, Evaluation of pork colour: prediction of visual sensory quality of meat from instrumental and computer vision methods of colour analysis. Meat Sci 65:909-918 (2003).

62. Khliji S, van de Ven R, Lamb TA, Lanza M and Hopkins DL, Relationship between consumer ranking of lamb colour and objective measures of colour. Meat Sci 85:224-229 (2010).

This article is protected by copyright. All rights reserved. 
Figure 1. Visual appraisal of leg chops of kids from two rearing systems through 8 days of display.

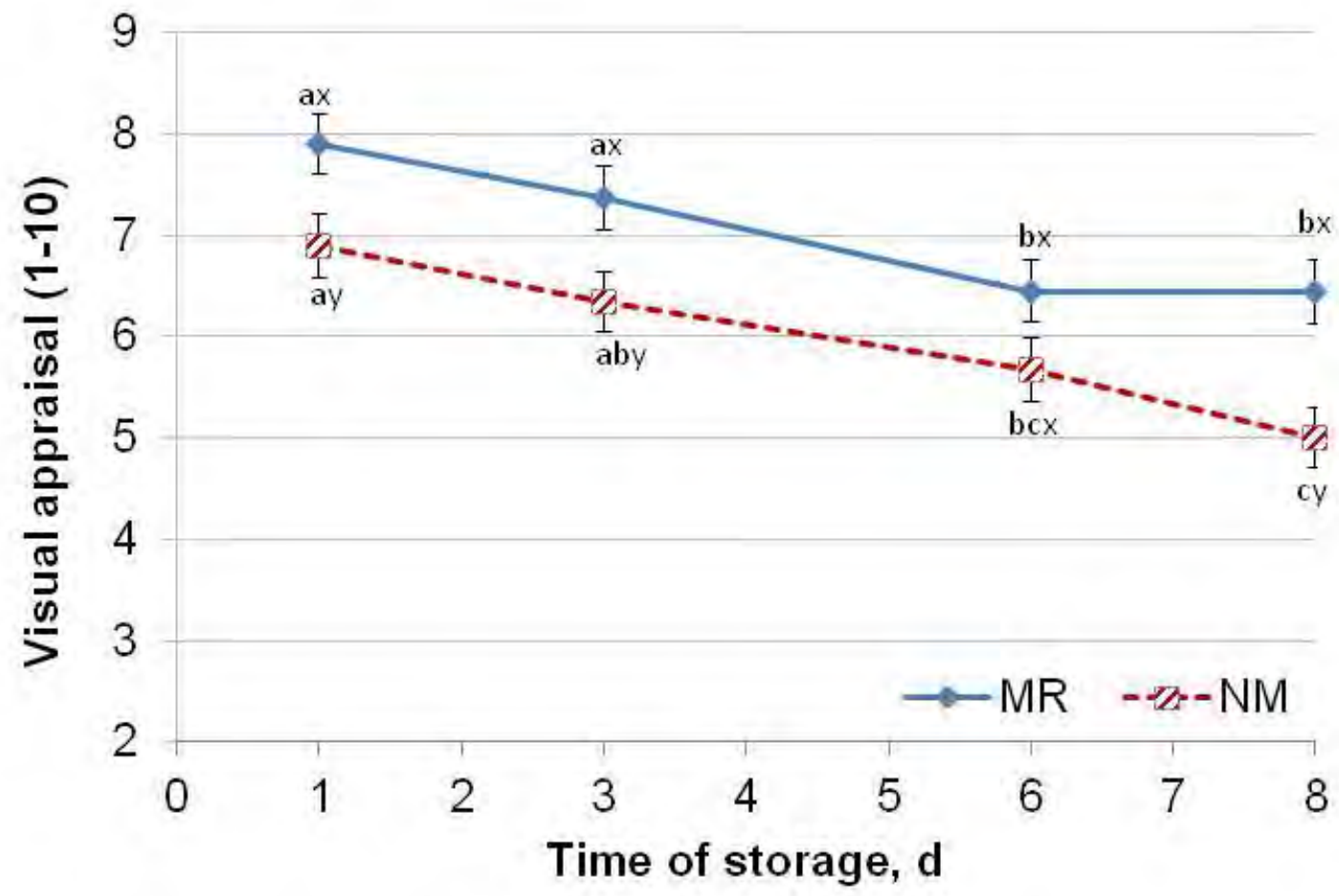

MR, milk replacer; NM, natural milk from dams

$\mathrm{a}, \mathrm{b}$, different letters indicate significant differences among times of display within a rearing system

$\mathrm{x}, \mathrm{y}$, different letters indicate significant differences among rearing systems

This article is protected by copyright. All rights reserved. 
Figure 2. Purchase intention for leg chops of kids from two rearing systems through 8 days of display.

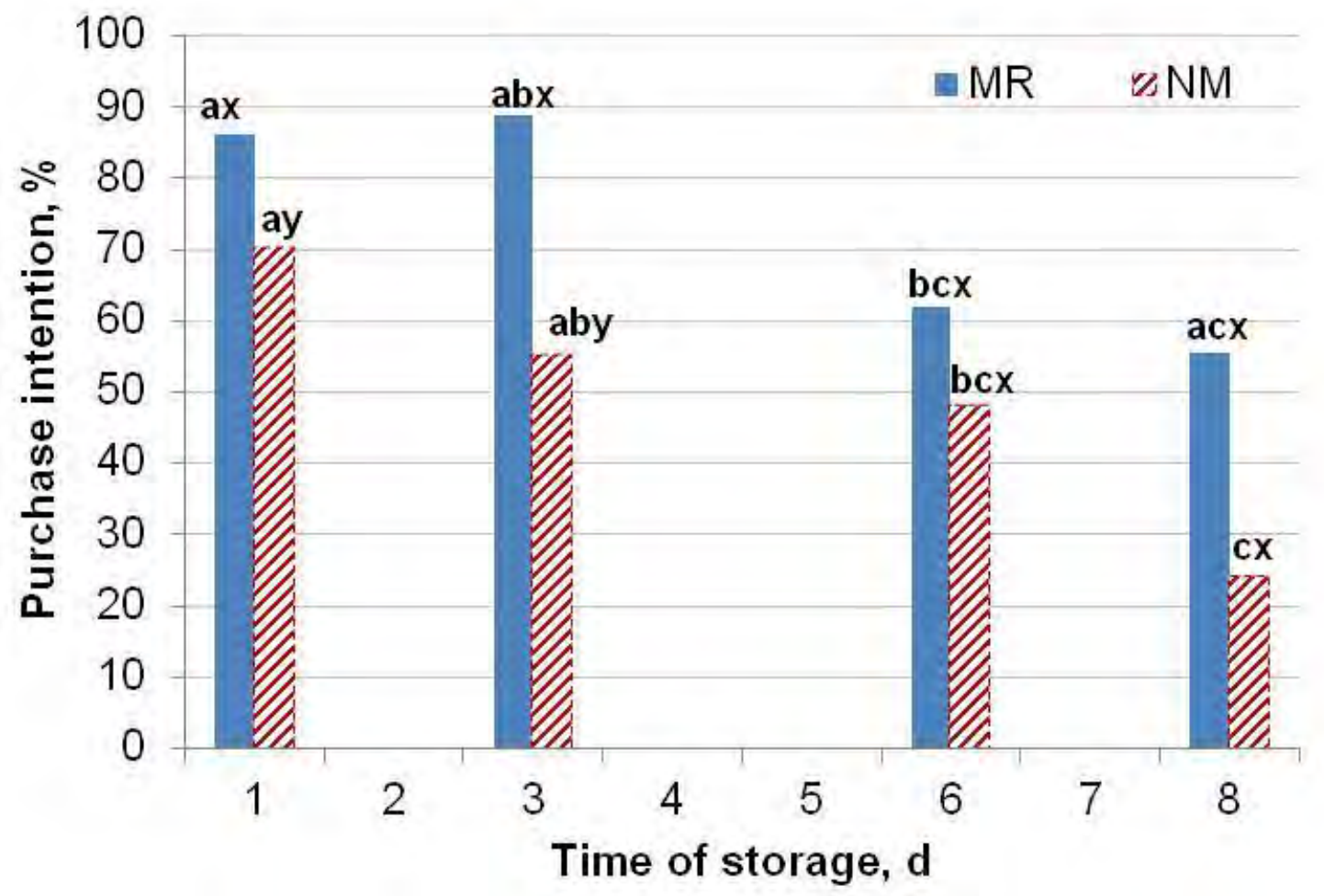

MR, milk replacer; NM, natural milk from dams

$\mathrm{a}, \mathrm{b}, \mathrm{c}$, different letters indicate significant differences among times of display within a rearing system

$\mathrm{x}, \mathrm{y}$, different letters indicate significant differences among rearing systems

Table 1. Significance of the representability test for selected chops.

\begin{tabular}{|c|c|c|c|}
\hline & $\mathrm{L}^{*}$ & $h_{a b}$ & $C_{a b}^{*}$ \\
\hline Population of chops $(\mathrm{P})^{1}$ & 0.093 & 0.062 & 0.767 \\
\hline Muscle (M) & 0.267 & 0.145 & 0.332 \\
\hline $\mathrm{P} * \mathrm{M}$ & 0.785 & 0.851 & 0.601 \\
\hline
\end{tabular}

${ }^{1}$ Population of chops: selected chops vs. the whole population of chops.

The test was performed with the values measured with illuminant D65.

$\boldsymbol{h}_{\boldsymbol{a b}}=$ hue angle $=\tan ^{-1}\left(\frac{b *}{a *}\right) \cdot 57.29 ; \boldsymbol{C}_{\boldsymbol{a b}}^{*}=$ chroma $=\sqrt{(\boldsymbol{a} *)^{2}+(b *)^{2}}$

This article is protected by copyright. All rights reserved. 
Table 2. Instrumental color of leg chops from kids reared with milk replacer (MR) or natural milk from their dams (NM).

\begin{tabular}{lccccc}
\hline & $\mathrm{L}^{*}$ & $\mathrm{a}^{*}$ & $\mathrm{~b}^{*}$ & $h_{a b}$ & $C_{a b}^{*}$ \\
\cline { 2 - 6 } Rearing system & & & & & \\
MR & 42.35 & 7.98 & 6.37 & 38.26 & 10.23 \\
NM & 39.65 & 9.36 & 5.48 & 30.02 & 10.94 \\
s.e. & 0.439 & 0.203 & 0.267 & 1.223 & 0.252 \\
Time of storage & & & & & \\
1 d & 40.27 & $9.88^{\mathrm{a}}$ & 6.68 & 34.34 & $12.04^{\mathrm{a}}$ \\
$3 \mathrm{~d}$ & 40.98 & $8.85^{\mathrm{b}}$ & 6.16 & 34.41 & $10.85^{\mathrm{b}}$ \\
6 d & 41.02 & $8.19^{\mathrm{bc}}$ & 5.44 & 33.08 & $9.91^{\mathrm{bc}}$ \\
$8 \mathrm{~d}$ & 41.71 & $7.77^{\mathrm{c}}$ & $5.41^{\mathrm{b}}$ & 34.73 & $9.54^{\mathrm{c}}$ \\
s.e. & 0.619 & 0.287 & 0.378 & 1.730 & 0.357 \\
Muscle & & & & & \\
$\quad$ biceps femoris & 41.48 & $8.23^{\mathrm{b}}$ & $5.29^{\mathrm{b}}$ & 32.08 & $9.85^{\mathrm{b}}$ \\
semimembranosus & 40.46 & $8.42^{\mathrm{b}}$ & $5.40^{\mathrm{b}}$ & 33.27 & $10.08^{\mathrm{a}}$ \\
semitendinosus & 41.06 & $9.37^{\mathrm{a}}$ & $7.07^{\mathrm{a}}$ & 37.07 & $11.83^{\mathrm{a}}$ \\
s.e. & 0.536 & 0.282 & 0.304 & 1.498 & 0.303 \\
Significance & & & & & \\
Rearing system & $<0.001$ & $<0.001$ & 0.025 & $<0.001$ & 0.056 \\
Time of display & 0.452 & $<0.001$ & 0.069 & 0.911 & 0.001 \\
$\quad$ Muscle & 0.409 & 0.006 & $<0.001$ & 0.063 & $<0.001$ \\
\hline
\end{tabular}

MR, milk replacer; NM, natural milk from dams; s.e., standard error

$\dagger$ Interactions were not significant $(p>0.05)$.

$\boldsymbol{h}_{a b}=$ hue angle $=\tan ^{-1}\left(\frac{b *}{a *}\right) \cdot 57.29 ; C_{a b}^{*}=$ chroma $=\sqrt{(a *)^{2}+(b *)^{2}}$

This article is protected by copyright. All rights reserved. 
Table 3. Shelf life of leg chops according to the purchase intention of consumers estimated by survival analysis.

\begin{tabular}{llclc}
\hline \multirow{3}{*}{ Rearing system } & Strata & Median, d & S.e. & Significance \\
\cline { 2 - 5 } & MR & 8 & 1.0 & 0.005 \\
& NM & 6 & 0.8 & \\
Sex & Women & 6 & 0.6 & 0.112 \\
& Men & 6 & 0.9 & \\
Age, yr. & & & & \\
& 26 & 6 & 2.3 & 0.655 \\
& $26-40$ & 6 & 1.2 & \\
& $41-55$ & 6 & 1.0 & \\
\hline
\end{tabular}

MR, milk replacer; NM, natural milk from dams

This article is protected by copyright. All rights reserved. 
Table 4. Pearson correlations of the residuals of visual appraisal and instrumental color for each muscle and illuminant.

\begin{tabular}{|c|c|c|c|c|c|c|c|c|c|}
\hline \multirow{3}{*}{$\begin{array}{l}\text { Muscle } \\
\text { Illuminant } \\
\text { Color variable }\end{array}$} & \multicolumn{6}{|c|}{ Semitendinosus } & \multicolumn{3}{|c|}{ Muscles average $^{1}$} \\
\hline & \multicolumn{2}{|c|}{ D65 } & \multicolumn{2}{|c|}{$\mathrm{C}$} & \multicolumn{2}{|c|}{ A } & D65 & $\mathrm{C}$ & $\mathrm{A}$ \\
\hline & $a^{*}$ & $C_{a b}^{*}$ & $a^{*}$ & $C_{a b}^{*}$ & $a^{*}$ & $C_{a b}^{*}$ & $\mathrm{~L}^{*}$ & $\mathrm{~L}^{*}$ & $\mathrm{~L}^{*}$ \\
\hline Correlation (r) & 0.17 & 0.21 & 0.16 & 0.21 & 0.19 & 0.19 & -0.22 & -0.22 & -0.21 \\
\hline Significance & 0.012 & 0.001 & 0.015 & 0.002 & 0.004 & 0.005 & 0.001 & 0.001 & 0.002 \\
\hline
\end{tabular}

${ }^{1}$ Correlations between the average $\mathrm{L}^{*}$ of the three muscles.

$\boldsymbol{C}_{\boldsymbol{a b}}^{*}=\boldsymbol{c h r o m a}=\sqrt{(\boldsymbol{a} *)^{2}+(\boldsymbol{b} *)^{2}}$

Only significant correlations with $\mathrm{P}<0.05$ are shown. Biceps femoris and semimembranosus color variables were not significantly correlated with visual appraisal and these data are not shown in the table.

This article is protected by copyright. All rights reserved. 
Table 5. Statistics for the tested machine learning models.

\begin{tabular}{|c|c|c|c|c|c|c|c|}
\hline \multirow[b]{3}{*}{ Average error } & \multirow[b]{2}{*}{ Global $^{1}$} & \multicolumn{3}{|c|}{ Iluminant $^{2}$} & \multicolumn{3}{|c|}{ Muscles $^{3}$} \\
\hline & & D65 & $\mathrm{C}$ & A & $\mathrm{BF}$ & $\mathrm{SM}$ & ST \\
\hline & 1.2 & 1.2 & 1.2 & 1.3 & 1.3 & 1.2 & 1.2 \\
\hline Relative error & 0.81 & 0.79 & 0.79 & 0.85 & 0.86 & 0.80 & 0.80 \\
\hline Correlation (r) & 0.52 & 0.55 & 0.55 & 0.49 & 0.47 & 0.50 & 0.50 \\
\hline \multicolumn{8}{|c|}{ Variables included in each model in the algorithm } \\
\hline & $\mathrm{L}^{*}\left(\square^{4}-\mathrm{D} 65\right)$ & $\mathrm{L}^{*}\left(\square^{4}\right)$ & $\mathrm{L}^{*}\left(\square^{4}\right)$ & $b^{*}(\mathrm{ST})$ & $\mathrm{L}^{*}$ & $a^{*}$ & $\mathrm{~L}^{*}$ \\
\hline & $b^{*}(\mathrm{SM}-\mathrm{D} 65)$ & $h_{a b}\left(\square^{4}\right)$ & $h_{a b}\left(\square^{4}\right)$ & $b^{*}(B F)$ & $a^{*}$ & $h_{a b}$ & $a^{*}$ \\
\hline & $h_{a b}(\mathrm{SM}-$ & $h_{a b}$ & $h_{a b}(\mathrm{SM})$ & $h_{a b}$ & $b^{*}$ & $C_{a b}^{*}$ & $b^{*}$ \\
\hline & L* (ST-D65) & $h_{a b}(\mathrm{ST})$ & $h_{a b}(\mathrm{ST})$ & & $h_{a b}$ & & $h_{a b}$ \\
\hline & a* (ST-D65) & $h_{a b}(\mathrm{BF})$ & $h_{a b}(\mathrm{BF})$ & & $C_{a b}^{*}$ & & \\
\hline & $h_{a b}(\mathrm{ST}-\mathrm{A})$ & $C_{a b}^{*}$ & $C_{a b}^{*}(\mathrm{ST})$ & & & & \\
\hline & & $\mathrm{a} *(\mathrm{ST})$ & $\mathrm{a}^{*}(\mathrm{ST})$ & & & & \\
\hline & & $b^{*}(\mathrm{ST})$ & $\mathrm{b}^{*}(\mathrm{ST})$ & & & & \\
\hline
\end{tabular}

${ }^{1}$ Data for the five color variables of the three muscles measured, with the three illuminants used as inputs.

${ }^{2}$ Data for the five color variables of the three muscles and the averaged color measured, with each illuminant used as input.

${ }^{3}$ Data for the five color variables of each muscle measured with the D65 illuminant used as input.

${ }^{4}(\square)$, Average color variable for the three muscles.

$\mathrm{BF}$, biceps femoris; SM, semimembranosus; ST, semitendinosus;

Semitendinosus

$\boldsymbol{h}_{\boldsymbol{a b}}=$ hue angle $=\tan ^{-1}\left(\frac{b *}{a *}\right) \cdot 57.29 ; \boldsymbol{C}_{a b}^{*}=$ chroma $=\sqrt{(\boldsymbol{a} *)^{2}+(b *)^{2}}$

This article is protected by copyright. All rights reserved. 